\title{
ВИПРАВДУВАЛЬНИЙ ВИРОК - АКТ РЕАБІЛІТАЦІї ПІДСУДНОГО
}

\author{
НАУМОВА Анна Олександрівна - кандидат юридичних наук, доцент \\ кафедри кримінального права та кримінології факультету №6 ХНУВС \\ ORCID:https://orcid.org/0000-0002-4273-8068 \\ УДК 343.1 \\ DOI 10.32782/NP.2021.2.20
}

\begin{abstract}
В статье исследованъи точки зори ученъих относительно понятия «оправдательный приговор» и усовершенствовано его определение. Сделанъ въводъ о том, ито вълнесение оправдательного приговора предусматривает полную реабилитацию подсудимого без какихлибо изъятий, влечет возмещение имущественного, бизического и морального вреда, восстановление трудовъх, пенсионнъхх, жилищных и инъхх прав реабилитированного, включая восстановление спечцальньх, военных и почетных званий, класснъгх чинов, возвращение государственнъгх наград и тому подобное.

Ключевые слова: оправдательнъий приговор, основания оправдательного приговора, непричастность лица к совершению уголовного правонарушения, реабилитация.
\end{abstract}

Постановка проблеми

Відповідно до ст. 3 Конституції України людина, іiї права і свободи $\epsilon$ найвищою цінністю. Визнання, дотримання і захист прав і свобод людини і громадянина - це обов'язок держави. Ця конституційно-правова норма визначає зміст ст. 2 КПК, згідно 3 якою призначенням кримінального судочинства $є$ не тільки захист особи, суспільства та держави від кримінальних правопорушень, а й захист особи від незаконного та необгрунтованого обвинувачення, засудження, обмеження іï прав і свобод.У процесі досягнення цілей кримінального судочинства виправдання і осуд розглядаються як нерозривно пов'язані між собою сторони кримінально-процесуальної діяльності, а тому виправдувальний вирок $є$ таким же авторитетним актом правосуддя, як і обвинувальний вирок. Судова практика свідчить про незначну кількість виправдувальних вироків в Україні, оскільки щорічно виправдовується менш одного відсотка. Водночас незначна кількість осіб $(0,4 \%)$ зверталася до судових органів України про поновлення порушених прав і свобод, відшкодування шкоди, завданої незаконним і необгрунтованим кримінальним переслідуванням, незаконним засудженням. Вказане свідчить про необхідність системного вивчення та нормативного удосконалення виправдувального вироку як акту реабілітації.

Аналіз останніх досліджень і публікацій

Проблеми ухвали вироку досить детально досліджувалися у наукових роботах Г. Н. Агєєвої, В. Д. Адаменка, Н. А. Ахундова, М. І. Бажанова, В. Д. Бринцева, Ю. М. Грошевого, В. Я. Дорохова, В. Р. Заблоцького, А. З. Кобликова, О. Ф. Куцової, А. М. Ларіна, Р. Н. Ласточкіної, Е. А. Матвієнко, 3. Р. Мірецького, Т. Р. Морщакової, I. Д. Перлова, І. ᄉ. Петрухіна, М. 3. Строговича, А. Н. Толочко, Ф. Н. Фаткулліна та ін. Окремі автори зверталися і до проблеми виправдувального вироку: У. Д. Арсеньєв, Ю. М. Грошевой, А. Я. Дубінський, Ю. А. Іванов, В. З. Аукашевич, М. Ф. Маліков, Я. О. Мотовіловкер, Р. М. Оганесян, П. Ф. 


\section{Кримінальне право, кримінальний процес та криміналістика}

Пашкевич, В. М. Савицький, Ю. Н. Седлецький, Н. Н. Скворцов та ін. Вказані праці мають велике наукове та практичне значення, однак потребують удосконалення в частині визнання виправдувального вироку актом реабілітації.

Мета статті полягає у вивченні та аналізі теоретичних положень, присвячених проблемам постановлення виправдувального вироку, розкритті його підстав, визначенні його процесуального значення та визнанні виправдувального вироку актом, який сприяє реабілітації невинуватого.

\section{Виклад основного матеріалу}

У юридичній літературі відсутне однозначне тлумачення ознак виправдувального вироку. Так, В. Т. Маляренко зазначив, що «вирок підбиває підсумки всієї процесуальної діяльності органів досудового слідства, прокуратури і суду. У вироку суд вирішує питання про винуватість або невинуватість підсудного, про застосування або незастосування до нього покарання. Вирок, що набрав законної сили, набуває силу закону, тобто стає для цієї справи таким же обов'язковим, як закон» [1, с. 202]. Переконливою є позиція Ю. Ю. Чурилова, який вважає, що виправдувальний вирок - це акт правосуддя, що володіє певними внутрішніми (законність, обгрунтованість, справедливість) і зовнішніми (винятковість, обов'язковість, незмінність, преюдиціальність) властивостями, що мають соціально-політичне, правове, етичне і виховне значення, ухвалюється судом першої або апеляційної інстанції та полягає у встановленні невинуватості (не встановлення винуватості) особи у вчиненні злочину за пред'явленим обвинуваченням і підтриманому в ході судового розгляду.

Постанова виправдувального вироку пов'язана зі встановленням підстав виправдання, регламентація яких грунтується на наступних правилах:

1) підстави виправдання повинні бути сформульовані в законі у вичерпному вигляді;

2) виправдання має відбуватися лише по одній з перелічених у законі підстав;
3) усі підстави виправдання повинні тягти однакові правові наслідки у вигляді реабілітації виправданого [2, с. 6].

Погоджуємося $з$ точкою зору I. Г. Алейнікова, який вважає виправдувальний вирок актом державної влади, який реабілітує громадянина. Суд від імені держави проголошує його невинуватість, відновлюе його честь, добре ім'я, статус повноправності [3, с. 73]. Правильно визначає I. $\mathcal{A}$. Петрухін, що виправдувальний вирок - акт «самообмеження держави». I слідчий, і прокурор, i суд - органи держави, які виражають його волю, але при винесенні виправдувального вироку вони поставлені у відносини субординації: суд встановлюе, що слідство проведено необ'єктивно, упереджено, винного не встановлено, підсудний не винен. Правоохоронні органи, хоча i не задоволені виправдувальним вироком, змушені йому підкоритися [ 4, с. 41].

У кримінально-процесуальній науці немає єдиної думки в питанні про те, чи є законність, обгрунтованість і справедливість властивостями вироку чи вимогами до вироку. Погоджуємося 3 твердженнямH. М. Суханової, що вимоги, які пред'являються до вироку, - це умови, правила, якими суд зобов'язаний керуватися при його ухваленні, а властивості - це ознака того, що відбулося, результат виконання цих вимог. Отже, законність, обгрунтованість, вмотивованість і справедливість є вимогами, що пред'являються до вироку суду, у тому числі й до виправдувального. До властивостей вироку слід віднести:

- законну силу виправдувального вироку, яка окреслює межі його дії, - тільки за даною кримінальною справою і щодо осіб, зазначених у вироку;

- загальнообов’язковість виправдувального вироку, що включає дві умови: поперше, він є обов'язковим для всіх державних органів, громадських об'єднань, організацій, підприємств, установ, посадових осіб та громадян; по-друге, рішення, що містяться в ньому, підлягають обов'язковому виконанню на всій території держави;

- винятковість виправдувального вироку, що означає неможливість повторного притягнення особи до кримінальної відпо- 
відальності за вчинення злочину, за обвинуваченням у якому вона була виправдана;

- преюдиціальність виправдувального вироку, яка полягає в тому, що встановлені обставини не викликають сумнівів у суду і визнаються судом, прокурором і не потребують додаткової перевірки;

- презумпцію істинності вироку, яка існує лише до тих пір, поки він не набрав законної сили [5, с. 14-16].

На основі викладеного вважаємо, що виправдувальний вирок є законним, обгрунтованим та справедливим офіційним актом правосуддя по визнанню невинуватості підсудного в інкримінованому кримінальному правопорушенні, який усуває процесуальні помилки, що були допущені органами досудового розслідування, шляхом виправдання та реабілітації невинуватого.

Підстави ухвалення виправдувального вироку зазначені в частині 1 ст. 373 КПК України, а саме у разі, якщо не доведено, що

1) вчинено кримінальне правопорушення, у якому обвинувачується особа;

2) кримінальне правопорушення вчинене обвинуваченим;

3) у діянні обвинуваченого $є$ склад кримінального правопорушення.

Виправдувальний вирок

т а к о ж ухвалюється при встановленні судом підстав для закриття кримінального провадження, передбачених пунктами 1 та 2 частини першої статті 284 КПК України , тобто встановлена відсутність події кримінального правопорушення; встановлена відсутність у діянні складу кримінального правопорушення.

У юридичній літературі окремі дослідники вважають недосконалим та двозначним формулювання такого поняття, як «недоведена вина». Як свідчать матеріали практики, мають місце факти, коли в ході досудового слідства проти обвинуваченого збирається значна кількість доказів, що створюють видимість їх переконливості. Водночас при ретельному дослідженні цих доказів під час судового слідства встановлено,що коли мало місце випадання із групи доказів тільки одного доказу, то весь ланцюг доказів руйнувався, а 3 ним руйнувалося і звинувачення [6, с. 101]. Так, на думку В. В. Соловйова, при недоведеності участі обвинуваченого у вчиненні злочину, по-перше, нереалізованим залишається завдання швидкого і повного розкриття злочину; по-друге, знижується спеціальна і загальнопревентивна значимість діяльності правоохоронних органів, оскільки особа, яка вчинила злочин, залишається безкарною; по-третє, відсувається на невизначений час або зовсім стає неможливим усунення негативних наслідків злочину; по-четверте, цей результат негативно позначається і на престижі правоохоронної діяльності в громадській думці, особливо у випадках вчинення тяжких злочинів: адже соціальна справедливість торжествує лише щодо особи, чия справа припинена [7,c. 156-157].

Таким чином, особа лише юридично визнається невинуватою при закритті справи у зв'язку з недоведеністю їі участі у вчиненні злочину, однак імовірність того, що вона насправді злочин скоїла, зовсім не виключається [8, с. 53]. Відповідно до принципу презумпції невинуватості недоведена вина тотожна доведеній невинуватості. Між цими двома категоріями немає i не може бути розходжень ні з точки зору юридичних наслідків, ні щодо моральної оцінки. Закриття кримінальної справи за недоведеністю участі обвинуваченого у вчиненні злочину повністю знімає 3 нього обвинувачення і всяку підозру [10, с. 53].

у чинному кримінально-процесуальному законодавстві України недоведеність у вчиненні злочину є підставою реабілітації (ч. 1 ст. 373 КПК України). Правовий аналіз кримінально-процесуального законодавства окремих держав СНД дозволяє визначити іншу підставу реабілітації, а саме - непричетність особи до вчинення злочину. Так, у статті 39 КПК Республіки Казахстан унормовані підстави реабілітації. Це виправдувальний вирок суду, постанова органу кримінального переслідування про закриття кримінальної справи 3 підстав, передбачених пунктами 1, 2, 5, 7, 8 частини першої статті 37 КПК Республіки Казахстан , тобто за відсутністю дії злочину; за відсутністю в діянні складу злочину; за від- 


\section{Кримінальне право, кримінальний процес та криміналістика}

сутністю скарги потерпілого; стосовно особи, відносно якої є вирок суду, що набрав законної сили за тим же обвинуваченням, або інша не скасована судова постанова, що встановила неможливість кримінального переслідування; щодо особи, про відмову від кримінального переслідування якої за тим же обвинуваченням є не скасована постанова органу кримінального переслідування) [11]. Аналогічно у російському кримінальному процесуальному законодавстві непричетність підозрюваного або обвинуваченого до вчинення злочину є підставою для закриття кримінальної справи ( пункт 1 частини 1 статті 27 КПК РФ ). Правовий аналіз кримінально-процесуального законодавства окремих держав, вивчення матеріалів практики , результати проведених нами досліджень переконують у доцільності законодавчого унормування зазначеної проблеми. Пропонуємо внести деякі зміни до ст. 284 КПК України, шляхом унормування у пункті 3 обставини - як достовірно встановлена непричетність особи до вчинення злочину.

Процесуальне ж значення виправдувального вироку виражається в тому, що виправдання підсудного $є$ одним 3 найважливіших способів виправлення процесуальних помилок. Винесення виправдувального вироку означає визнання судом підсудного невинним у скоєнні інкримінованого йому злочину. Крім цього, постанова виправдувального вироку, який набрав законної сили, передбачає повну реабілітацію підсудного без будь-яких вилучень, що тягне відшкодування майнової, фізичної та моральної шкоди, відновлення трудових, пенсійних, житлових та інших прав реабілітованого, включаючи відновлення спеціальних, військових і почесних звань, класних чинів, повернення державних нагород тощо [12, с.55]

Таким чином, цінність виправдувального вироку - у його реальній здатності захищати і відновлювати порушені права людини, яка постраждала від незаконного кримінального переслідування. Аише виправдання підсудного, яке тягне за собою його повну реабілітацію, усуває всі моральні поневіряння та перешкоди, пов'язані iз пред'явленням особі необгрунтованого звинувачення, що нерідко супроводжується взяттям під варту, багатогодинними допитами, очними ставками, виїздами на місце події, нервовим вимотування і виснаженням.

\section{Висновки}

Аналіз законодавства та теоретичних положень, вивчення практики свідчить про те, що виправдувальний вирок є законним, обгрунтованим та справедливим офіційним актом правосуддя по визнанню невинуватості підсудного в інкримінованому кримінальному правопорушенні, який усуває процесуальні помилки, що були допущені органами досудового розслідування, шляхом виправдання та реабілітації невинуватого. На основі правового аналізу кримінально-процесуального законодавства окремих держав, вивчення матеріалів практики, результатів проведених нами досліджень вважаємо доцільним унормувати у пункті 3 ст. 284 КПК України ще одну підставу ухвалення виправдувального вироку - достовірно встановлену непричетність особи до вчинення кримінального правопорушення.

Винесення виправдувального вироку передбачає повну реабілітацію підсудного без будь-яких вилучень, що тягне відшкодування майнової, фізичної та моральної шкоди, відновлення трудових, пенсійних, житлових та інших прав реабілітованого, включаючи відновлення спеціальних, військових і почесних звань, класних чинів, повернення державних нагород тощо.

\section{入ітература}

1. Маляренко В. Т. Суд, правоохоронні та правозахисні органи України . Київ, 2006. 890 c.

2. Чурилов Ю. Ю. Оправдательный приговор в российском судопроизводстве : автореф. дис. ... канд. юрид. наук: 12.00.09. Воронеж, 2009. 22 с.

3. Алейніков Г. I. Виправдувальний вирок. Херсон, 2008. 98 с.

4. Петрухин И. А. Реабилитация. Законодательство. 2004. № 3. С. 74-84. 
5. Суханова Н. H. Постановление оправдательного приговора в российском уголовном судопроизводстве : автореф. дис. ... канд. юрид. наук : 12.00.09. Иркутск, 2008. 24 с.

6. Строгович М. С. Право обвиняемого на защиту и презумпция невиновности. М. : Наука, 1984. 143 с.

7. Соловьев В. В. Проблемы прекращения уголовного дела за недоказанностью и его правовые последствия. Совершенствование правоохранительной деятельности ОВД : сб. трудов ВЮЗШ МВД СССР. М., 1990.C. 156-157.

8. Мотовиловкер Я. О. О принципах объективной истины, презумпции невиновности и состязательности процесса : учебное пособие / под ред.: Кругликова А. А. Ярославль : Изд-во Яросл. ун-та, 1978. $96 \mathrm{c}$.

9. Ковалев В. А. Прекращение уголовного дела в условиях деятельности органов дознания : учеб. пособие. М. : МССШМ МВД СРСР, 1990. 64 с.

10. Уголовно-процессуальный кодекс Республики Казахстан от 13 декабря 1997 р. № 206-I. Закондательство Казахстана. Базы данных URL: https://pavlodar.com/ zakon/?dok $=00147$

11. Чурилов, Ю.Ю. Актуальные проблемы постановления оправдательного приговора в российском уголовном судопроизводстве / под науч. ред. З.Ф. Ковриги. М. : Волтерс Клувер, 2010. 256 с.

\section{List of References}

1. Malyarenko V. T. Sud, pravookhoronni ta pravozakhysni orhany Ukrayiny . Kyyiv, 2006. $890 \mathrm{~s}$.

2. Churilov Yu. Yu. Opravdatelnyiy prigovor $\mathrm{v}$ rossiyskom sudoproizvodstve : avtoref. dis. ... kand. yurid. nauk: 12.00.09. Voronezh, 2009. 22 s.

3. Aleynikov H. I. Vypravduval'nyy vyrok. Kherson, 2008. 98 s.

4. Petruhin I. L. Reabilitatsiya. Zakonodatelstvo. 2004. \# 3. S. 74-84.

5. Suhanova N. N. Postanovlenie opravdatelnogo prigovora $\mathrm{v}$ rossiyskom ugolovnom sudoproizvodstve : avtoref. dis. ... kand. yurid. nauk : 12.00.09. Irkutsk, 2008. 24 s.
6. Strogovich M. S. Pravo obvinyaemogo na zaschitu i prezumptsiya nevinovnosti. M. : Nauka, 1984. 143 s.

7. Solovev V. V. Problemyi prekrascheniya ugolovnogo dela za nedokazannostyu i ego pravovyie posledstviya. Sovershenstvovanie pravoohranitelnoy deyatelnosti OVD : sb. trudov VYuZSh MVD SSSR. M., 1990.S. 156-157.

8. Motovilovker Ya. O. O printsipah ob'ektivnoy istinyi, prezumptsii nevinovnosti i sostyazatelnosti protsessa : uchebnoe posobie / pod red.: Kruglikova L. L. Yaroslavl : Izd-vo Yarosl. un-ta, 1978. 96 c.

9. Kovalev V. A. Prekraschenie ugolovnogo dela v usloviyah deyatelnosti organov doznaniya : ucheb. posobie. M. : MSSShM MVD SRSR, 1990. 64 s.

10. Ugolovno-protsessualnyiy kodeks Respubliki Kazahstan ot 13 dekabrya 1997 r. \# 206-I. Zakondatelstvo Kazahstana. Bazyi dannyih URL: https://pavlodar.com/ zakon/?dok $=00147$

11. Churilov, Yu.Yu. Aktualnyie problemyi postanovleniya opravdatelnogo prigovora v rossiyskom ugolovnom sudoproizvodstve / pod nauch. red. Z.F. Kovrigi. M. : Volters Kluver, 2010. $256 \mathrm{~s}$.

A.A. NAUMOVA

Candidate of Law, Associate Professor of the Department of Criminal Law and Criminology Faculty No. 6 Kharkiv National University of Internal Affairs ORCID: https: //orcid.org/0000-00024273-8068 e-mail: naymova85@i.ua

\section{ВИПРАВДУВААЬНИЙ ВИРОК - АКТ РЕАБІЛІТАЦІЇ ПІДСУДНОГО}

У статті досліджено точки зори науковців щодо поняття «виправдувальний вирок», удосконалено його визначення як законного, обгрунтованого та справедливого офіційного акту правосуддя по визнанню невинуватості підсудного в інкримінованому кримінальному правопорушенні, який усуває процесуальні помилки, що були допущені органами досудового розслідуван- 


\section{Кримінальне право, кримінальний процес та криміналістика}

У статті досліджено точки зори науковиів щодо поняття «виправдувальний вирок» та удосконалено його визначення. Зроблено висновки про те, що винесення виправдувального вироку передбачає повну реабілітацію підсудного без будь-яких вилучень, шо тягне відикодування майнової, фбізичної та моральної шкоди, відновлення трудових, пенсійних, житлових та інших прав реабілітованого, включаючи відновлення спещіальних, військових $i$ почесних звань, класних чинів, повернення державних нагород тощо.

Ключові слова: виправдувальний вирок, підстави виправдувального вироку, непричетність особи до вчинення кримінального правопорушення, реабілітація.

ня, шляхом виправдання та реабілітації невинуватого Здійснено аналіз норм кримінального-процесуального кодексу України та зарубіжних країн, які визначають підстави постановлення виправдувального вироку, та запропоновано унормувати у пункті 3 ст. 284 КПК України ще однієї підстави ухвалення виправдувального вироку - достовірно встановлену непричетність особи до вчинення кримінального правопорушення. Виправдувальний вирок є підсумком всієї попередньої кримінально-процесуальної діяльності. Сутність виправдувального вироку відображають такі його ознаки, як встановлення винуватості обвинуваченого у вчиненні злочину (встановлено алібі або факт вчинення кримінального правопорушення іншою особою), визнання і посвідчення його невинуватості, а також відновлення в колишніх правах та відшкодуванні спричиненої шкоди. Зроблено висновки, що винесення виправдувального вироку передбачає повну реабілітацію підсудного без будь-яких вилучень, що тягне відшкодування майнової, фізичної та моральної шкоди, відновлення трудових, пенсійних, житлових та інших прав реабілітованого, включаючи відновлення спеціальних, військових і почесних звань, класних чинів, повернення державних нагород тощо.

Ключові слова: виправдувальний вирок, підстави виправдувального вироку, непричетність особи до вчинення кримінального правопорушення, реабілітація. 